\title{
Antibodies to Candida albicans in hospital patients with and without spinal injury and in normal men and women
}

\author{
P. H. EVERALL, C. A. MORRIS, AND DELIA F. MORRIS
}

From the Public Health Laboratory and Department of Microbiology, Mytton Oak Road, Shrewsbury, and the Family Planning Association, Health Centre, Wellington, Shropshire

SYNOPSIS The presence of serum agglutinins and precipitins to Candida albicans in men and women who had impaired bladder function following spinal injury is compared with that in other patients in hospital and in apparently fit men and women. Antibody levels which have commonly been regarded as significant were found in 35 of 76 patients who had urinary candidiasis; in 10 of 52 patients who had spinal injury without urinary candidiasis; in eight of 57 patients who had neither of these conditions, and in nine of 191 normal men and women. Observations are made on the antigens involved in these reactions and on the need for standardization of both reagents and techniques.

It is common for patients to develop urinary tract infections following spinal injury and for them to be treated with antibiotics. As a complication of this, Candida albicans sometimes colonizes the bladder where it is found usually as a transitory, but occasionally as a persistent, organism in the urine, with or without the presence of pus, and commonly without any obvious systemic disturbances in the patient. No treatment is necessary unless there is some evidence of impending invasive candidiasis. One measure of systemic involvement is the presence of circulating antibodies. Although Winner (1955) regarded agglutinins to $C$. albicans as of little or no diagnostic significance, Stallybrass (1964) found that precipitating antibodies to $C$. albicans were produced in response to systemic but not to superficial infection. The present study was undertaken to compare the levels of antibody to $C$. albicans in patients with impaired neurophysiological function of the bladder (resulting from spinal injury) with those found in patients with postoperative urinary candidiasis but no spinal injury and in normal persons.

\section{Materials}

Human sera were collected from 376 persons; they can be divided into four groups:

1. A 'normal' population of 191 persons: 83 men (water works employees) and 108 women of childReceived for publication 26th April 1974. bearing age (family planning clinic patients). A vaginal swab was also taken from the women.

2. Seventy-nine patients in a spinal injuries unit: 56 men and 23 women. Thirteen of these men and 14 of the women were known to have urinary candidiasis.

3. Fifty-seven orthopaedic patients ( 29 men and 28 women) without spinal injuries but of a comparable age range to the previous group.

4. Forty-nine patients in a general hospital who developed urinary candidiasis $(25$ males and 24 females).

Sera were not inactivated and were stored at $-20^{\circ} \mathrm{C}$.

C. albicans (A) precipitating antigen, obtained in the lyophilized state from the Mycological Reference Laboratory' of the Public Health Laboratory Service, was dissolved in phosphate-buffered saline (Dulbecco solution A) to give a solution containing $2.5 \mathrm{mg}$ per $\mathrm{ml}$. Sodium azide (to $1 \mathrm{~g} /$ litre) was then added.

A preparation of mannan derived from C. albicans was obtained from the same source and treated in the same manner. (This was not available until towards the end of the investigation.)

BORATE AGAR GEL pH $8 \cdot 6$ (IONIC

STRENGTH $0 \cdot 05$ )

This has the composition:

$\begin{array}{llllll}\text { Boric acid } & \ldots & \ldots & \ldots & \ldots & 6.7 \mathrm{~g}\end{array}$ 
Sodium borate (decahydrate) $\quad$. $13.4 \mathrm{~g}$

Distilled water .. $\quad . . \quad \ldots \quad \ldots 1000 \mathrm{ml}$

Oxoid agar no. $1 \quad \ldots \quad \ldots \quad \ldots \quad 10 \mathrm{~g}$

Ethylene diamine tetraacetic

$\begin{array}{lllll}\text { acid disodium salt } & \ldots & \ldots & \ldots & 0.25 \mathrm{~g}\end{array}$

The agar is dissolved in half the water by heating; the other reagents and the remainder of the water are then added.

BARBITONE AGAR GEL PH $8 \cdot 6$ (IONIC

STRENGTH 0.05)

This has the composition:

Sodium diethyl barbiturate .. $\quad . \quad 10.3 \mathrm{~g}$

Diethyl barbituric acid $\quad . . \quad \ldots .184 \mathrm{~g}$

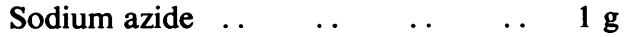

Oxoid agar no. $1 \quad \ldots \quad \ldots \quad \ldots \quad 10 \mathrm{~g}$

Distilled water .. $\quad \ldots \quad \ldots \quad \ldots 1000 \mathrm{ml}$

It is prepared in the same manner as is borate agar gel.

COOMASSIE BRILLIANT BLUE R STAIN

This has the composition:

Coomassie Brilliant Blue R (Searle

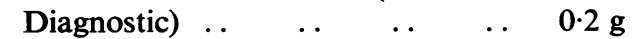

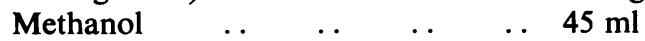

Acetic acid $\quad . \quad \ldots \quad \ldots \quad \ldots \quad \ldots 10 \mathrm{ml}$

Distilled water .. $\quad . . \quad \ldots \quad \ldots \quad 45 \mathrm{ml}$

SHEEP ANTI-C. albicans SERUM

(BURROUGHS WELLCOME)

This had no reference number but was dated February 1971. It was used as a positive control serum in both the double diffusion and agglutination tests.

\section{Methods}

\section{AGGLUTINATION TESTS}

\section{Preparation of the suspension}

Roux bottles containing glucose peptone agar were inoculated with an 18-hour culture of a stock strain of $C$. albicans $A$. After incubation for not more than 32 hours the growth was washed off in phosphatebuffered saline (PBS). The harvested cells were washed twice in PBS containing $1 \mathrm{~g} /$ litre of sodium azide, packed by centrifugation, and the packed cell volume of the suspension was measured. This suspension was distributed in convenient volumes into a series of screw-capped bottles and stored at $-20^{\circ} \mathrm{C}$. Before use in agglutination tests sufficient PBS containing 1 in 1000 sodium azide was added to each bottle to yield a $2 \%$ suspension of yeast cells.

\section{Performance of the test}

Sera were diluted with PBS and azide in a WHO tray to give a range of doubling dilutions commencing at $1 / 8$, each dilution being in a final volume of 0.4 $\mathrm{ml}$. One drop ( $0.02 \mathrm{ml})$ of a $2 \%$ Candida suspension was then added to each well, the whole mixed, and then left at room temperature for 24 hours. The deposit was resuspended by gently shaking and the results were read under oblique illumination against a black background. Under these conditions the Burroughs Wellcome sheep anti-C. albicans serum agglutinated the suspension to a dilution of $1 / 64$ whereas no agglutination was observed in PBS alone.

DOUBLE DIFFUSION TESTS

Molten borate agar was distributed in $2.5 \mathrm{ml}$ volumes per $5 \mathrm{cmm}$ petri dish on a level surface. When cool, patterns were cut with the use of the templates according to the plan below, using a no. 4 cork borer and a $2 \mathrm{~mm}$ diameter needle. The central cups

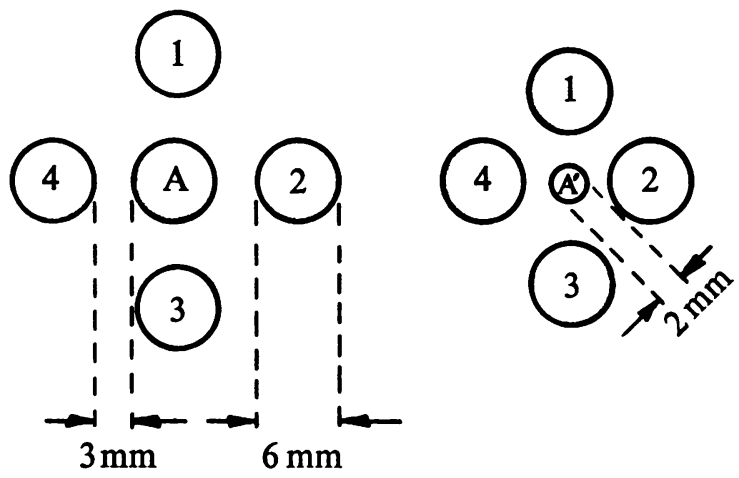

$A$ and $A^{\prime}$ were filled with the appropriate antigen $(2.5 \mathrm{mg} / \mathrm{ml})$. The sera under investigation, together with positive controls, were placed in the peripheral cups $1-4$, these again being just filled. (Each unknown serum was therefore tested at two ratios against the antigen, the volume of the large antigen cup $A$ to that of the small antigen cup $\mathbf{A}^{\prime}$ being approximately $9 \cdot 1$ ) (fig 1 ).

The plates were incubated at room temperature for four days, read, washed in azide saline for two days, dried, stained with Coomassie Brilliant Blue for 30 minutes, decolourized in a mixture of the solvents without the stain, dried and read again.

If precipitin lines were produced the sera were retested to elicit a reaction of identity with the Burroughs Wellcome control serum. Selected sera were also tested in a similar way against $C$. albicans mannan and, after absorption with $C$. albicans mannan, against $C$. albicans antigen. The procedure for absorption was as follows:

Two drops $(0.04 \mathrm{ml})$ of each serum under test were placed in adjacent peripheral cups: in one of these cups was placed one drop of $2.5 \%$ mannan 


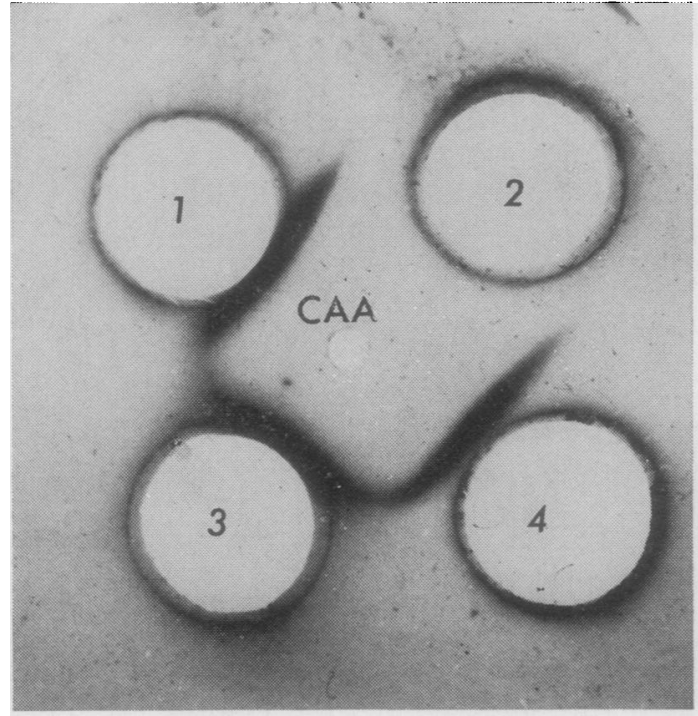

Fig 1

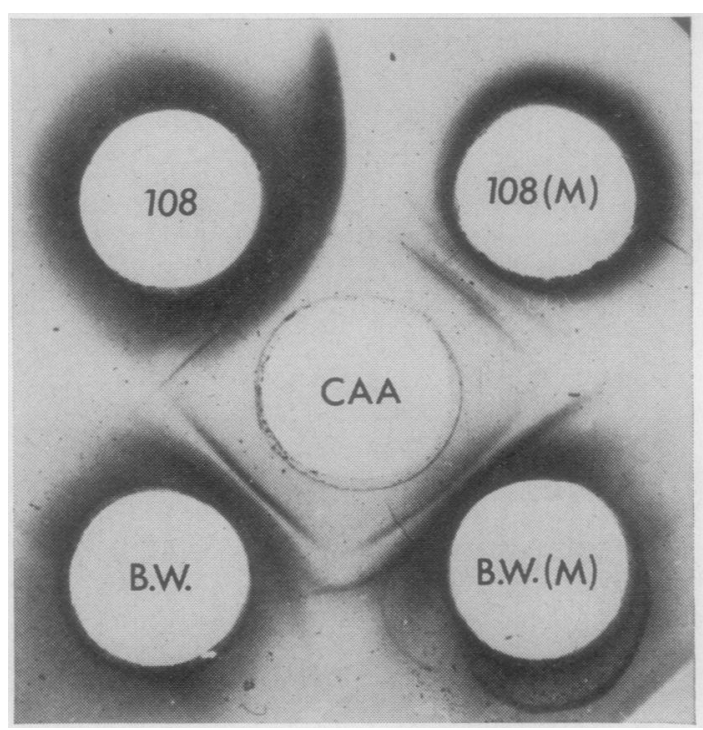

Fig 2

Fig 1 Routine screening of patients' serum (peripheral cups 1-4) against Candida albicans antigen (CAA) in the small central cup. The rather diffuse line produced by sera 1, 3, and 4 was shown in subsequent experiments to result from antibody to the mannan component.

Fig 2 Identification of Candida antibodies in human sera by simple absorption with mannan. Cup 108 contains serum from patient 108. Cup $108(M)$ contains the same serum absorbed with mannan. Cup BW contains sheep antiserum to $C A A$ and cup $B W(M)$ the same antiserum after absorption. The central cup contains $\mathrm{C}$ albicans antigen. Serum 108 is shown to contain three antibodies.

solution. The central cup was filled with $C$. albicans antigen (fig 2).

\section{IMMUNOELECTROPHORESIS TESTS}

These were carried out in a milieu either of barbitone or of borate buffers. The gel was poured to a depth of $2 \mathrm{~mm}$ on a plate of $10 \times 10 \mathrm{~cm}$ and after cutting a suitable pattern of troughs and holes, electrophoresis was carried out at 'constant current'. With a current of $25 \mathrm{~mA}$ flowing through each plate of the above dimensions a satisfactory separation was obtained in three to four hours.

\section{CULTURES}

Standard microbiological methods were used for examining urine samples from hospital patients and high vaginal swabs from the family planning clinic patients. Urine samples were catheter specimens and vaginal swabs were transported in Stuart's medium.

\section{Results}

AGgLUTININS TO $C$. albicans IN HUMAN SERA

Agglutinin titres of $1 / 64$ or more were found in two of 83 apparently healthy men. Such titres were, however, much more commonly found in male hospital patients with a spinal injury $(7 / 56)$ or in general hospital patients with urinary candidiasis $(11 / 25)$. In male hospital patients who had neither spinal injury nor urinary candidiasis, agglutinins at a level of $1 / 64$ or more were not found in any of the 29 sera examined. With women the pattern of serum agglutinins followed that of men with the exception that women in hospital with neither spinal injury nor urinary candidiasis showed high titres slightly more frequently than did normal women (table I).

Some patients' sera showed a prozone and some gave a coarse and others a fine agglutination reaction.

\section{PRECIPITINS TO $C$. albicans IN HUMAN} SERA

Fifty-one persons, including some apparently healthy men and women, were found to have precipitins reacting with the $C$. albicans antigen. The presence of precipitins was not always associated with agglutinins (table II) though it was more commonly so in patients who had urinary candidiasis (tables III and IV). 


\begin{tabular}{|c|c|c|c|c|c|c|c|c|c|c|}
\hline \multirow[t]{3}{*}{ Population } & \multicolumn{5}{|l|}{ Men } & \multicolumn{5}{|l|}{ Women } \\
\hline & \multicolumn{4}{|c|}{$\begin{array}{l}\text { Reciprocal of } \\
\text { Agglutinin Titre }\end{array}$} & \multirow[t]{2}{*}{ Total Patients } & \multicolumn{4}{|c|}{$\begin{array}{l}\text { Reciprocal of } \\
\text { Agglutinin Titre }\end{array}$} & \multirow[t]{2}{*}{ Total Patients } \\
\hline & 16 or less & 32 & 64 & 128 & & 16 or less & 32 & 64 & 128 & \\
\hline $\begin{array}{l}\text { Normal } \\
\text { Spinal injury } \\
\text { Other orthopaedic } \\
\text { Urinary candidiasis } \\
\text { (general hospital) }\end{array}$ & $\begin{array}{l}80 \\
42 \\
28 \\
11\end{array}$ & $\begin{array}{l}1 \\
7 \\
1 \\
3\end{array}$ & $\begin{array}{r}2 \\
6 \\
0 \\
10\end{array}$ & $\begin{array}{l}0 \\
1 \\
0 \\
1\end{array}$ & $\begin{array}{l}83 \\
56 \\
29 \\
25\end{array}$ & $\begin{array}{r}103 \\
13 \\
23 \\
12\end{array}$ & $\begin{array}{l}2 \\
7 \\
3 \\
3\end{array}$ & $\begin{array}{l}3 \\
2 \\
0 \\
6\end{array}$ & $\begin{array}{l}0 \\
1 \\
2 \\
3\end{array}$ & $\begin{array}{r}108 \\
23 \\
28 \\
24\end{array}$ \\
\hline
\end{tabular}

Table I Agglutinins to C. albicans

\begin{tabular}{|c|c|c|c|c|c|c|c|c|c|c|}
\hline \multirow[t]{3}{*}{ Population } & \multicolumn{5}{|l|}{ Men } & \multicolumn{5}{|l|}{ Women } \\
\hline & \multicolumn{4}{|c|}{$\begin{array}{l}\text { Reciprocal of } \\
\text { Agglutinin Titre }\end{array}$} & \multirow[t]{2}{*}{$\begin{array}{l}\text { Proportion of } \\
\text { Total Patients }\end{array}$} & \multicolumn{4}{|c|}{$\begin{array}{l}\text { Reciprocal of } \\
\text { Agglutinin Titre }\end{array}$} & \multirow[t]{2}{*}{$\begin{array}{l}\text { Proportion of } \\
\text { Total Patients }\end{array}$} \\
\hline & 16 or less & 32 & 64 & 128 & & 16 or less & 32 & 64 & 128 & \\
\hline $\begin{array}{l}\text { Normal } \\
\text { Spinal injury } \\
\text { Other orthopaedic } \\
\text { Urinary candidiasis } \\
\text { (general hospital) }\end{array}$ & $\begin{array}{l}1 \\
2 \\
1 \\
2\end{array}$ & $\begin{array}{l}0 \\
3 \\
0 \\
2\end{array}$ & $\begin{array}{l}1 \\
1 \\
0 \\
9\end{array}$ & $\begin{array}{l}0 \\
1 \\
0 \\
1\end{array}$ & $\begin{array}{r}2 / 83 \\
7 / 56 \\
1 / 29 \\
14 / 25\end{array}$ & $\begin{array}{l}1 \\
3 \\
3 \\
0\end{array}$ & $\begin{array}{l}2 \\
1 \\
2 \\
2\end{array}$ & $\begin{array}{l}2 \\
1 \\
0 \\
5\end{array}$ & $\begin{array}{l}0 \\
1 \\
2 \\
2\end{array}$ & $\begin{array}{l}5 / 108 \\
6 / 23 \\
7 / 28 \\
9 / 24\end{array}$ \\
\hline
\end{tabular}

Table II Agglutinins in 51 patients with precipitins to C. albicans

\begin{tabular}{|c|c|c|c|c|c|}
\hline \multirow[t]{2}{*}{ Population } & 1 & 2 & 3 & \multirow[b]{2}{*}{$\begin{array}{l}\text { Total of Columns } \\
1 \text { and } 3\end{array}$} & \multirow{2}{*}{$\begin{array}{l}\text { Total Patients in } \\
\text { Population Group }\end{array}$} \\
\hline & $\begin{array}{l}\text { Number with an } \\
\text { Agglutinin Titre of } \\
\text { 1/64 or More }\end{array}$ & $\begin{array}{l}\text { Number with } \\
\text { Precipitins }\end{array}$ & $\begin{array}{l}\text { Number with } \\
\text { Precipitins and Agglu- } \\
\text { tinin Titre of } 1 / 32 \text { or } \\
\text { less }\end{array}$ & & \\
\hline $\begin{array}{l}\text { Normal } \\
\text { Spinal injury with or } \\
\text { without coexisting urinary }\end{array}$ & 2 & 2 & 1 & 3 & 83 \\
\hline candidiasis & 7 & 7 & 5 & 12 & 56 \\
\hline $\begin{array}{l}\text { Other orthopaedic } \\
\text { Urinary candidiasis }\end{array}$ & 0 & 1 & 1 & 1 & 29 \\
\hline $\begin{array}{l}\text { (general hospital) } \\
\text { Spinal injury and coexist- }\end{array}$ & 11 & 14 & 4 & 15 & 25 \\
\hline ing urinary candidiasis & 3 & 2 & 1 & 4 & 13 \\
\hline
\end{tabular}

Table III Precipitins and 'significant' agglutinins to C. albicans in men

\begin{tabular}{|c|c|c|c|c|c|}
\hline \multirow[t]{2}{*}{ Population } & 1 & 2 & 3 & 4 & 5 \\
\hline & $\begin{array}{l}\text { Number with an } \\
\text { Agglutinin Titre of } \\
\text { 1/64 or More }\end{array}$ & $\begin{array}{l}\text { Number with } \\
\text { Precipitins }\end{array}$ & $\begin{array}{l}\text { Number with } \\
\text { Precipitins and Agglu- } \\
\text { tinin Titre of } 1 / 32 \text { or } \\
\text { less }\end{array}$ & $\begin{array}{l}\text { Total of Columns } \\
1 \text { and } 3\end{array}$ & $\begin{array}{l}\text { Total Patients in } \\
\text { Population Group }\end{array}$ \\
\hline \multirow{7}{*}{$\begin{array}{l}\text { Normal females } \\
\text { Spinal injury with or } \\
\text { without coexisting urinary } \\
\text { candidiasis } \\
\text { Other orthopaedic } \\
\text { Urinary candidiasis } \\
\text { (general hospital) } \\
\text { Spinal injury and coexist- } \\
\text { ing urinary candidiasis } \\
\text { Normal females with posi- } \\
\text { tive vaginal swabs for } \\
\text { C. albicans }\end{array}$} & 3 & 5 & 3 & 6 & 108 \\
\hline & 3 & 6 & 4 & 7 & 23 \\
\hline & 2 & 7 & 5 & 7 & 28 \\
\hline & 9 & 9 & 2 & 11 & 24 \\
\hline & 2 & 5 & 3 & 5 & 14 \\
\hline & 2 & 2 & 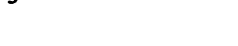 & 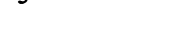 & 47 \\
\hline & 1 & 2 & 1 & 2 & 13 \\
\hline
\end{tabular}

Table IV Precipitins and 'significant' agglutinins to C. albicans in women 
Tables III and IV also show the number in each group studied who had either an agglutinin titre of $1 / 64$ or more, or precipitins, or both. These two tests taken together in this way confirm the conclusions stated above for the agglutinin tests alone.

IMMUNOCHEMICAL ANALYSIS OF THE

ANTIGENS USED IN THE DOUBLE

DIFFUSION TESTS

Simple double diffusion tests with sheep anti- $C$. albicans serum against the $C$. albicans antigen showed it to be a complex mixture. On immunoelectrophoresis in barbitone agar no fewer than seven separate components could be recognized (fig 3). These were characterized in terms of their electrophoretic mobility using human serum proteins as a reference. In this way there was distinguished one major component of pre-albumin mobility and lesser components of $\alpha_{1}, \alpha_{2}, \beta$, and $\gamma$ mobility. Electrophoresing in borate agar (fig 4) gave a similar pattern but the mobility of the $\gamma$ component increased to that of $\beta$.

In the same way analysis of the mannan preparation showed it to contain a fraction having $\gamma$ mobility in barbiturate agar and $\beta$ mobility in corate agar (figs 3 and 4).

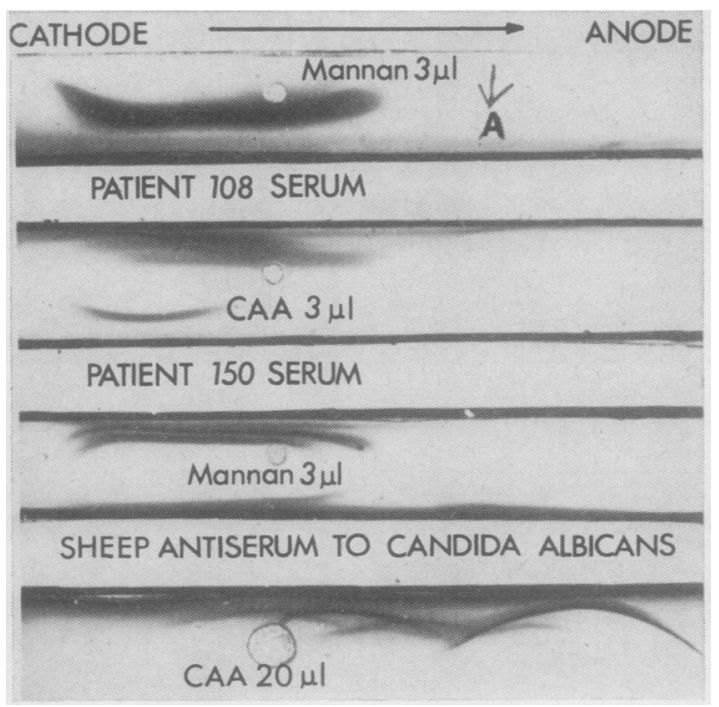

Fig 3
The $C$. albicans antigen had been thought to be relatively free from $C$. albicans mannan: these experiments showed that it contained quite enough to give a good precipitin line provided that the antigenantibody ratios were correctly adjusted for the system. Equally the sheep anti-C. albicans serum contained a small amount of anti-mannan. With experience it was found that precipitin lines of the mannananti-mannan system were often recognizable, being softer in outline and less dense than those produced with other antigen-antibody systems.

That a line was or was not due to mannan/antimannan was confirmed by the absorption experiments described above (fig 2 ) or by double diffusion tests in which the mannan was employed as antigen (fig 1). All sera from the control groups, viz, normal males, normal females, and 'other orthopaedic' patients which gave positive precipitin tests with the C. albicans antigen were further examined in this way: no antibody other than that to $C$. albicans mannan could be demonstrated.

\section{Discussion}

High agglutinin titres were not diagnostic of urinary candidiasis nor did their absence exclude the condi-

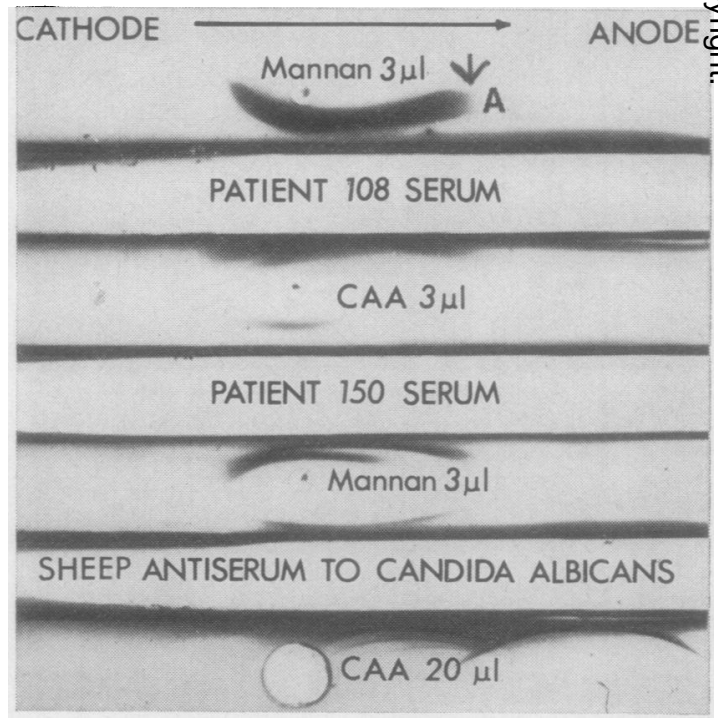

Fig 4

Fig 3 Immunoelectrophoretic analysis in barbitone agar of Candida albicans antigen (CAA) and mannan antigen employing two human sera and the Burroughs Wellcome sheep antiserum to $C A A$. A sample of normal human serum was analysed simultaneously on the same plate against anti human serum: ' $A$ ' indicates the centre of the albumin arc so produced.

Fig 4 As fig 3 but the analysis is carried out in borate agar. Note the increased mobility of the mannan fraction in both the $C A A$ and mannan antigens. 
tion. High agglutinin titres were found in only 14 of 38 men and 11 of 38 women with genitourinary candidiasis whereas comparable titres were found in about $2.5 \%$ of healthy men and women.

Damage to the bladder nerve supply caused by spinal injury can reduce bladder tone. We found no evidence that $C$. albicans in the bladder is more invasive (as judged by the presence of antibodies) in patients with a spinal injury than in other patients who have urinary candidiasis but no spinal injury.

It has been suggested that agglutinins to $C$. albicans are directed against the mannan component of the cell wall. Although our precipitin tests regularly identified precipitins to mannan, agglutinins and precipitins were not always both detectable in the same serum even if the agglutinating titre were high and it seems likely that some agglutinins are directed at components of the cell wall other than mannan.

Immunoelectrophoretic analysis of the $C$. albicans antigen used in our precipitin tests with the sheep anti- $C$. albicans serum identified seven components. The number of antigens identified in any mixture depends on the number of homologous antibodies in the polyvalent serum used for the analysis as well as the sensitivity of the particular technique employed. Using the two-dimensional immunoelectric method of Clarke and Freeman (1966), 78 watersoluble antigens have been identified in an homogenate of C. albicans (Axelson, 1973). The increased electrophoretic mobility of the mannan component when borate buffer is used instead of barbitone buffer is a property common to all polysaccharides having cis-hydroxyl groups.

Our precipitin tests were carried out at two antigenantibody ratios: had we tested at more ratios with smaller intervals the number of positive results could probably have been increased as would have been the case if the sera had been concentrated. Even so, if we had relied only on precipitin lines visible in the gel before staining many positive results would have been missed. Coomassie Brilliant Blue is an excellent stain for weak precipitin lines and is preferable to Amido Black for this purpose.

Confusion exists in the literature because many of the tests employed by different observers, although bearing the same name, have varied in their performance, in the materials employed, in the results they have given and the conclusions drawn from them. There is a real danger of serological tests for candidiasis falling into disrepute unless more standardized methods are accepted. Thus as recently as 1973, Jones, Brennan, and Kundsin reported that while the precipitin test did not differentiate local from systemic invasion with $C$. albicans, nonetheless it was of value because it did not give positive results with any of their blood donor control sera. Dolan and Stried in the same year found no precipitins in 50 blood bank donor sera. Both studies employed $\mathbf{S}$ antigen prepared by sonication followed by removal of cell walls by centrifugation. However, as can be seen from the experimental results reported by Taschdjian, Kozinn, Cuesta, and Toni (1972) it does contain cell wall mannan as a minor component. Preisler, Hasenclever, Leviton, and Henderson (1969) found precipitating antibody in the antemortem sera from only four of 14 persons dying of acute leukaemia in whom evidence of visceral candidiasis was found at necropsy. In none of these four patients was precipitating antibody directed solely against $\mathbf{S}$ antigen or solely against mannan. Taschdjian and her associates in an examination of sera from 'high risk' patients, found no precipitins in nine patients, shown at necropsy to be free of candida infection, and positive precipitin tests in 21 out of 24 patients, in whom systemic candidiasis was proved either in life or at necropsy. Chew and Theus (1967), by a combination of concentration of serum globulins and the choice of a sensitive technique, concluded that precipitating antibodies could be demonstrated in the sera of all healthy adults. Goldstein and Hoeprich (1972), recommending comparative titrations of agglutinating antibody as a means of identifying patients developing systemic candidiasis, said of the precipitin test that "while the discrepancies may reflect variations in methods of testing the significance of precipitins is uncertain at present'. Some workers appear to have tested sera and antigens at only one ratio, a common cause of false negative reactions in any gel diffusion test and perhaps particularly so with $C$. albicans, as has been suggested by Remington, Gains, and Gilmer (1972). For these reasons, we considered it necessary to define as carefully as we could the source of our materials and the techniques used, although the techniques are, with minor modifications, based on those described by Murray, Buckley, and Turner (1969).

Our results, particularly those with sera from our control groups, support the view that the presence of antibody to $C$. albicans mannan is of minor importance in the diagnosis of systemic candidiasis. Present hopes are that antibody production to other (protein) antigens of $C$. albicans might be a better indicator of systemic candidiasis. Certainly antibodies to these other antigens do not appear so liberally in our sera as do those to mannan and they are demonstrated more commonly in patients with candidiasis than in controls. Such differences may be quantitative rather than absolute and whatever test is devised for the future it is essential to ensure its standardization and to fix its level of sensitivity. Until such time as $C$. albicans antigen can be fractionated and defined, gel diffusion tests when used 
alone have no advantage over the more easily quantifiable agglutination test.

Probably in the present state of development of these tests, the most important contribution which any routine microbiological laboratory can make, presented with the patient at high risk from systemic candidiasis, is to retain at $-15^{\circ} \mathrm{C}$ a baseline serum specimen so that it can, if necessary, be examined with subsequent sera by a laboratory which specializes in this work (Kozinn, Mackenzie, Hasenclever, Protzman and Seelig, 1972.)

We are grateful to Dr D. W. R. Mackenzie and Miss C. M. Philpot for advice and for supplying us with reagents and to $\mathrm{Dr} F$. Jones for allowing us to examine his patients. We are indebted to $\mathrm{Mr} \mathrm{J}$. D. Hamlett who took the photographs.

footnote

${ }^{1}$ Since this work was completed we have been informed that a batch of $C$. albicans precipitating antigen free of mannan has been prepared by the Mycological Reference Laboratory.

\section{References}

Axelson, N. H. (1973). Quantitative immunoelectrophoretic methods as tools for a polyvalent approach to standardization in the immunochemistry of Candida albicans. Infect. Immunity, 7, 949-960.

Chew, W. H., and Theus, T. L. (1967). Candida precipitins, J. Immunol., 98, 220-224.

Clarke, H. G. M., and Freeman, T. (1966). A quantitative immunoelectrophoresis method. Protides Biol. Fluids, 14, 503-509.

Dolan, C. T., and Stried, R. P. (1973). Serologic diagnosis of yeast infections. Amer. J. clin. Path., 59, 49-55.

Goldstein, E., and Hoeprich, P. D. (1972). Problems in the diagnosis and treatment of systemic candidiasis. J. infect. Dis., 125, 190-192.

Jones, S. A., Brennan, M., and Kundsin, R. B. (1973). Candida serology: an aid in diagnosis of deep-organ candidiasis. J. surg. Res., 14, 235-237.

Kozinn, P. J., Hasenclever, H. F., Taschdjian, C. L., Mackenzie, D. W., Protzman, W. and Seelig, M. S. (1972). Problems in the diagnosis and treatment of systemic candidiasis. J. infect. Dis., 126, 548-9.

Murray, I. G., Buckley, H. R., and Turner, G. C. (1969). Serological evidence of candida infection after open-heart surgery. J. med. Microbiol., 2, 463-469.

Preisler, H. D., Hasenclever, H. F., Levitan, A. A., and Henderson, E. S. (1969). Serologic diagnosis of disseminated candidiasis in patients with acute leukemia. Ann. intern. Med., 70, 19-30.

Remington, J. S., Gains, J. D., and Gilmer, M. A. (1972). Demonstration of candida precipitins in human sera by counter immunoelectrophoresis. Lancet, 1, 413-414.

Stallybrass, F. C. (1964). Candida precipitins. J. Path. Bact., 87 89-97.

Taschdjian, C. L., Kozinn, P. J., Cuesta, M. B., and Toni, E. F. (1972) Serodiagnosis of candidal infections. Amer. J. clin. Path., 57, 195-205.

Winner, H. I. (1955). A study of Candida albicans agglutinins in human sera. J. Hyg. (Lond.), 53, 509-512. 